\title{
Recruitment Advertising for Antarctic Personnel: \\ Between adventure and routine
}

Hanne E. F. NIELSEN (University of Tasmania, Australia)

Hanne.Nielsen@utas.edu.au

Cyril JAKSIC (Lincoln University, New Zealand)

Cyril.Jaksic@lincolnuni.ac.nz 


\section{Abstract}

This paper examines how Antarctica has been depicted in recruitment material, and compares the expectations set up in the advertising imagery with the reality of expeditioners' experiences. Textual analyses of advertisements and job descriptions are used to reveal dominant themes, including the trope of extremity, while interviews with those who have spent time on the ice provide reflections on the actual challenges encountered when working in Antarctica, such as boredom. Much of the popular discourse around Antarctica continues to centre on the Heroic Era (1895 - 1922), a time of exploration typified by men pitting themselves against nature and striding out into unchartered expanses of ice. Although modern day life on Antarctic stations differs markedly from the extreme conditions experienced by early explorers, the continent continues to be associated with notions of toughness and extremity. We argue that in some cases, advertisements may actually target the wrong audience. This has important implications for how an Antarctic station as a workplace is conceptualized, and then experienced by those who head south, with potential detrimental effects. 


\section{Men Wanted: Advertising Antarctica as Extreme}

The phrase "going to the ends of the earth" is usually used in a metaphorical sense, but when it comes to the recruitment of Antarctic personnel, the term can be taken quite literally. Antarctica is located at the frozen ends of the earth, out of reach and out of minds for most. Yet it is also a workplace for scientists, field staff, cooks, mechanics, pilots, and a wide range of other support personnel. This has been the case ever since the first expeditions ventured south towards Terra Australia Incognita, in search of marine mammals or geographic "firsts". Those who work in Antarctica, and ensure that the stations function effectively all year round, have been described by Maddison (2014, p. 1) as "the krill in the food chain of Antarctic discovery". Personal motivations for heading south vary, but recruitment advertisements play an important role in attracting personnel and shaping expectations.

It is telling that a job announcement, supposedly written by Ernest Shackleton, has endured as one of the most famous Antarctic texts. The much-circulated (and oftreproduced) recruitment notice read as follows:

Men wanted for Hazardous Journey. Small wages, bitter cold, long months of complete darkness, constant danger, safe return doubtful. Honor and recognition in case of success.

The advertisement itself is most likely to have been apocryphal - the first printed reference dates to 1944 (Elmore, 1944), and exhaustive searches of period newspapers have revealed no sign, despite offers of rewards (Stephenson, 2016). And yet, the famed lines continue to appear in popular culture: they have been 
reproduced on t-shirts, posters, mugs, and served as the central idea in campaigns for unrelated products and locations, such as the city of Detroit (Burn, 2009). As Leane (2012, p. 85) puts it, the advertisement is "a Heroic-Era fiction that has entered into communal memory". 'Men Wanted' has come to be used as shorthand for the 'Heroic Era' of Antarctic exploration, evoking at a glance ideas of heroism, masculinity, and endurance.

The ideas of extremity and adventure that have been associated with Antarctica have also been valuable in a marketing context. Early expeditions had media backing, and received funds in exchange for newsworthy narratives of derring-do. For instance, Carsten Borchgrevink's 1899 Southern Cross expedition was financed by newspaper baron George Newnes (Borchgrevink, 1901). Richard Byrd's 1933 expedition has been described as "the most media-saturated event in the history of the geographical exploration of Antarctica" (Matuozzi, 2002, p. 234) thanks to associations with The New York Times, Paramount Pictures, and radio broadcasters. The ability to sell a story was vital to an expedition's finances - and adventure, danger, and extremity were central to the expected drama. For this reason, most Antarctic expedition leaders of the Heroic Era enlisted ghost-writers to help them write their official accounts, and to foreground elements of drama and extremity. Such accounts - and accompanying photographs - then circulated amongst wide reading publics.

Most people will never actually visit Antarctica, so the imagined version of the place they carry in their minds is far more real for them than the actual ice. This representation is informed by various cultural inputs including diaries, literature, film, 
music, photography and theatre. Scholars such as Philpott and Leane (2016), Glasberg (2012), and Yusoff (2007) have examined representations of Antarctica across a range of media, teasing out the common associations and themes including heroism, extremity, fragility, and transformation. Berger (2005, p.166) explains how "In scholarly discourse about works of art of all kinds, the subjects of analysis are generally referred to as texts." In the Antarctic context, primary texts are also powerful; Robert Falcon Scott's diaries continue to capture imaginations, while Frank Hurley's iconic 1912 photograph of Mawson's men bent double as they battle the blizzard at Cape Dennison neatly encapsulates the idea of men taking on nature. Such texts have helped to shape the Antarctic imaginary of the extreme that still persists today.

Antarctica has been framed in a range of ways over the course of its human history. The continent has been variously seen as a place for profit (by early whalers and sealers); a place for heroes (evident in the term Heroic Era); a place of purity and wilderness (wilderness and aesthetic values are both enshrined in the 1991 Protocol on Environmental Protection to the Antarctic Treaty, or 'Madrid Protocol'); but also a fragile place in need of protection (particularly pertinent in the age of the Anthropocene, with the spectre of climate change ever present) (Nielsen, 2017, p. 193). Such themes are not mutually exclusive - they can operate simultaneously, with various frames more or less dominant within different temporal or national contexts. As "ways of seeing are historically, geographically, culturally and socially specific" (Rose, 2007, p. 12), the context in which a particular representation occurs also needs to be accounted for. Nevertheless, notions of heroism and extremity 
remain closely associated with the far south, and both play an important role in the cultural imagination.

The idea of Antarctica as a place of extremes continues to manifest in the frequently cited description of the continent as the highest, driest, coldest, and windiest place on Earth (Ackley, 2012, Barbarito, Baldanza, \& Peri, 2001, Palinkas, 1989; 1992; 2003, Palinkas, Gunderson, Johnson, \& Holland, 2000, Peri, Barbarito, Barattoni, \& Abraham, 2000). For vehicle, machinery, and clothing manufacturers, such superlatives represent the ultimate testing ground, and this has proved a valuable association for a number of companies that have capitalised on their Antarctic connections. Examples include the Singer sewing machine that accompanied Robert Falcon Scott on the Terra Nova expedition and survived "severe tests" (Singer advertisement, 1913, p. 89); the Everyready Prestone antifreeze that protected Byrd during three expeditions "under the worst possible freeze-up conditions" (Byrd and Poulter, 1931, p. 20); the Rolex that survived "the worst winter in the world" (Rolex advertisement, 1987); or the Ray-Ban sunglasses that were styled for fashion but "proven in the Antarctic" (Vintage Sunglasses Shop). Such products leverage their Antarctic association in order to impress audiences in less extreme parts of the world. Van der Watt and Swart (2016, p. 137) write how "like in other extreme environments," the domination over nature "became and remained a key sign of masculine fitness in Antarctica". This association with toughness is also manifest in reports of Antarctic 'firsts', such as the first car to cross the continent (Hyundai) (Fung, 2017), or the first band to play concerts on all seven continents within one year (Metallica) (Coleman, 2013). Such representations of Antarctica in marketing continue to reprise and reinforce the extremity theme. 


\section{Antarctica Today}

The explorers of the Heroic Era lived in draughty wooden huts and travelled south to endure years of no contact with the outside world. However, these days, Antarctica is much less 'out of reach', and far more comfortable for those who come to stay. Many parts of the continent are accessible by aircraft, and daily flights serve Antarctica during the summer season (weather permitting). Transport by land has also been facilitated by infrastructure developments. For instance, those travelling to the South Pole from McMurdo Station can travel along the 'South Pole Traverse', a $1,600 \mathrm{~km}$ long packed snow trail where crevasses have been filled and terrain has been levelled for safer and easier rides (Lyne, 2004). While Amundsen took more than two months to reach the South Pole from the Ross Ice Shelf in 1911, Maria Leijerstam took just under eleven days to travel a similar distance on a tricycle in 2013 (Guinness World Records, n.d.). Thanks to advances in both technology and infrastructure, the continent is more accessible than ever before.

Today's Antarctic stations stand in stark contrast to the first shelters built by early explorers. They offer almost all the comfort of a holiday resort: private rooms, laundry facilities, all meals catered for by a chef, and a wide variety of leisure options such as a gym, reading area, television, and in some cases even a pool table (Jacob, 2012, p. 72). Some stations also have a greenhouse, allowing for the 
consumption of fresh fruits and vegetables even in the middle of the Antarctic winter (Bamsey et al., 2015). Modern stations are not only heated, but also allow for warm showers, while Wi-Fi access makes it possible for expeditioners to keep 'liking' their friends' party pictures on social media throughout their Antarctic stay. In addition, many National Antarctic Programmes have payed particular attention to the architectural design of stations, and aim to make those who live there feel good. For instance, for the construction of Halley VI, Lebanese cedar has been chosen for its special scent, and spaces have been opened to feel more inclusive (Broughton, 2013). Several other stations have been specifically designed to ensure expeditioners come into contact with each other on a regular basis throughout the long winter months, in light of work on environmental cognition and perception (Carrère, 1990; Suedfeld, 1998, p.97). The sum of these changes means that Antarctica is no longer a place to endure, but rather a place to enjoy.

The energy and money spent to make sure winter-overs are comfortable in their station is not pure altruism from the National Antarctic Programmes; an Antarctic station is foremost a workplace. Given the cost and the time of recruiting, training and transporting employees, National Antarctic Programmes have to make sure that, once on site, the personnel will perform at their best. This is particularly true when it comes to selecting year-round teams. As Walton (2013, p. 49) puts it, "a small community can be a difficult place to live, so selecting the right people to overwinter is crucial". So, how do National Antarctic Programmes recruit the individuals who will best work together as a team down in the south Polar Regions? The text in recruitment advertisements may have advanced since the "Men Wanted" advertisement first appeared, but the function is similar. When it comes to 
recruitment advertisements, "the product is the job offer" (Ryan et al, 2000, p. 355), and that job must be framed to appeal to desired candidates. The following section analyses two recent examples of advertisements designed to attract potential employees to positions in Antarctica, before examining the experiences of those who have responded to such calls.

\section{Antarctic Roles: “Like No Other Job in the World”}

Taking a closer look at modern-day Antarctic recruitment advertisements reveals that the theme of Antarctic extremity is alive and well - and being used to actively encourage people into positions with National Antarctic Programmes. (It is also present in advertisements for positions such as postmaster at Port Lockroy, the "Penguin Post Office," (Antarctic Heritage Trust 2017) but advertisements published by trusts and private companies are outside the scope of this particular study). The award-winning 'Field Assistants' advertisement for the British Antarctic Survey (BAS) (2010), as seen in Figure 1, brings notions of extremity to the fore. The full-page advertisement is dominated by an image of a blizzard, with a solitary figure and a partially obscured tent in the bottom third. This echoes imagery familiar from the Heroic Era of exploration, such as Frank Hurley's photograph of men doubled over against the wind at Cape Dennison. The main text appeals to the viewer's assumed capability, reading "The fuel is stored 10 metres to your left. But you already knew that." In order to understand what the advertisement is for, it is necessary for the viewer to push the foregrounded image to the edges of their attention. By focusing instead on the fine print in the body text, the reader will find further details of the job, 
and contact details (while "The UK is 8591 miles to your North," the advertisement reveals that "The route to join us is $1.3 \mathrm{~cm}$ below", directing attention to the contact details section). In this regard, the advertisement presents a first test for prospective applicants. Art Director De Mornay Davies (n.d.) described how this specific "ad captured the excitement and challenge of the role by showing how deserted you are out on the field". The advertisement's ability to evoke the harsh Antarctic environment was recognised by others in the advertising industry. 'Field Assistants' won a prize for Best Copywriting at the Recruitment Business Awards 2010 (The Drum 2010), and was a finalist in the 2011 RAD Recruitment Advertising Awards in the Print Advertising category (De Mornay Davies, n.d.).

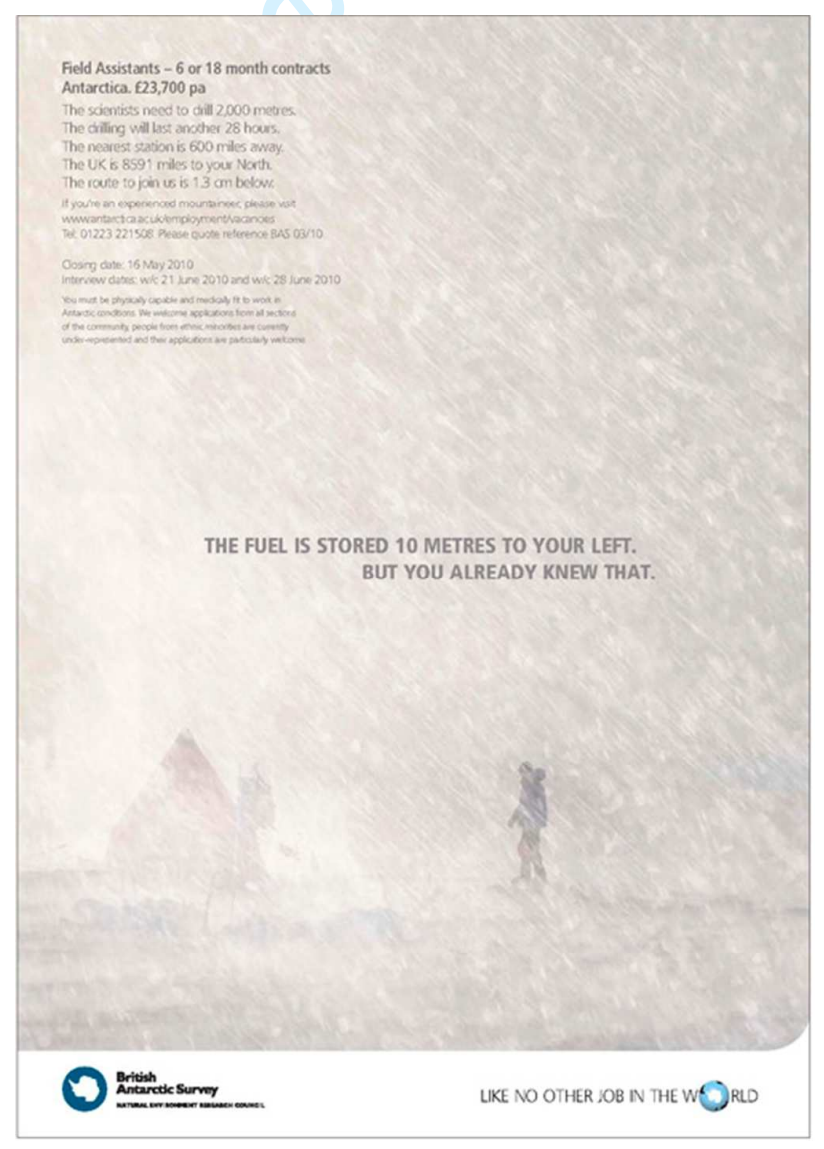


Figure 1. 'Field Assistants' advertisement for the British Antarctic Survey (Art Director De Mornay Davis (n.d.).) Image: British Antarctic Survey.

This BAS recruitment advertisement ran with the slogan "Like no other job in the world" in the bottom right hand corner. The 'o' features an image of the globe, centred on Antarctica. This combination of slogan and image builds upon the idea of Antarctic exceptionalism that sets the continent apart from other parts of the world. As Chaturvedi (2011, p. 22) explains, the underlying reasoning for Antarctic exceptionalism "has been that specific polar attributes and issues related to the Antarctic demand and deserve an exclusive treatment on their own merit." This exceptionalism is problematic in today's society, because as Hemmings (2009, p. 55) puts it, "globalisation now denies us the capacity to treat anywhere differently and thereby disables the principle of Antarctic exceptionalism". Writing from a historian's perspective, Maddison (2014, p. 198) too urges his readers to see Antarctica as a place "joined to the wider history of humanity". Nevertheless, Antarctic exceptionalism remains a selling point, imbuing the continent with an aura of uniqueness. The imagery used in the BAS advertisement sets up the expectation that the job advertised will be exceptional, and different to jobs anywhere else in the world. While field assistants do get to spend plenty of time in remote field camps, for many other staff this is not the case - most jobs at Antarctic stations are mundane, consisting of routine maintenance of the station and its surrounds. Such tasks are neither glamorous nor exotic enough to warrant being depicted on a poster. Given this, the combination of the extreme image and "like no other" slogan could lead to false expectations of what working in Antarctica is really like; snowstorms and spread sheets are tackled with very different skills. 
Imagery as an Invitation: "Picture Yourself Here?"

Imagery is a powerful tool for attracting potential employees. When recruiting for the 2017/18 season the Australian Antarctic Division (AAD) used the tagline "Picture yourself here?" The phrase was superimposed over Antarctic landscapes that featured ice cliffs, penguins, sunsets, and trekking expeditioners, and appeared in social media postings, on recruitment websites, and in print advertisements. A fullpage AAD advertisement in Virgin Australia's inflight magazine Voyeur (circulation 429,000 ) showcases emperor penguins in front of a towering ice face (Pacific Magazine, 2017, p. 77). The headline invites the viewer into the scene, by asking a direct question, whilst also evoking the urge to photograph the Antarctic. It then offers a way to make that imagined experience of standing amongst the penguins into a reality, thanks to the subheading: "Work and live in Antarctica." Smaller text clarifies the jobs available: "Now recruiting for electricians, chefs, carpenters, plumbers, diesel mechanics, communications officers, plant operators, aircraft support and other professional and support roles." Unlike job advertisements on recruitment websites, which are usually very specific, this is a broad sweep of positions. It targets personalities rather than specific skill sets, by implying that those who like adventure and beautiful scenery should come and practice their job in the far south, regardless of profession. 
Rather than appeal to a small number of technically competent applicants, the AAD advertisement is designed to prompt the viewers to imagine themselves in the Antarctic, with all of the wildlife and sublime icescapes that entails. Tellingly, the buildings, airstrips, motor vehicles and offices that will feature in the work (and living) environment of successful candidates are not mentioned at all. The imagery used in the recruitment advertisement is instead designed to catch the viewer's attention, and to resonate with their existing notions of Antarctica. While it is possible that recruits will find themselves in these kinds of situations (visiting a penguin colony at the face of a glacier), for most this would be an exceptional experience, and a far cry from their everyday jobs around the station. Sisodia and Chowdhary (2012, p. 81) argue that companies need to view their recruitment advertisements as being just as "powerful as corporate and brand advertising"; in addition to promoting vacant positions, recruitment material can help shape attitudes towards the business itself. In this case, the recruitment advertisement stands as an advertisement for the available roles, as well as for the AAD and the country's wider interests in the continent. Australia considers $42 \%$ of Antarctica to be 'Australian Antarctic Territory' (Geoscience Australia, n.d), so those interests are not insignificant. Given that very few people will ever visit Antarctica - let alone work there - the advertisement serves a further function: to keep Antarctica alive in the imaginations of the wider Australian public. That imagined version is overwhelmingly visual, characterized by penguins and ice - hence the use of such imagery here, where instantly recognizable visual elements act as shorthand for the continent.

Reading the Fine Print 
Should the Antarctic imagery in the initial advertisements prove appealing, potential applicants are usually offered a link to the National Antarctic Programme's website where they can learn more about the specific job descriptions. One might think that, at this point, the information would provide a more realistic depiction of what the position in question actually entails. However, the detailed job descriptions often sound equally as dramatic as the initial imagery has suggested, meaning those who have been hooked by the initial imagery encounter further language that reinforces extreme or heroic stereotypes about Antarctica. For instance, the British Antarctic Survey asks potential applicants whether they could imagine "working thousands of miles from home experiencing life in one of the most extreme places on Earth" (British Antarctic Survey, n.d a) and promises readers that "people who go to Antarctica are often amazed by what they see and do" (British Antarctic Survey, n.d. b). The Australian Antarctic Division (n.d. a) informs plumbers that their job will be "constantly varied and interesting" and recommends that their electricians should come prepared with "a sense of adventure" (Australian Antarctic Division, n.d. b).

The description of Antarctica as the "highest, driest, windiest and coldest continent" has been used by National Antarctic Programmes in the UK, Norway, Australia, India, and the USA (British Antarctic Survey, n.d. c; Norwegian Polar Institute, n.d.; Australian Antarctic Division, 2002; National Centre for Antarctic and Ocean Research, n.d.; United States Antarctic Program, n.d.) while the French Polar Institute (n.d.) promptly informs those who visit its site that with the coldest temperatures in Antarctica, any normally dressed individual "freezes to death in less than a minute" ["meurt de froid en moins d'une minute"]. These descriptions of the 
Antarctic environment, though true, can be misleading and set certain expectations relating to the everyday environment in which employees will have to work. False expectations, created in part by advertising recruitment imagery and language, can lead to problems further down the track. Job advertisements can be dense with both visual and verbal cues that call upon pre-existing notions, including that of Antarctica the extreme; Ryan et al (2000, p. 359) observe that "in most cases, recruitment advertising has more information to convey to the reader than commercial or product advertising". But how does this notion of extremity in the Antarctic stack up against the reality for those who respond to modern day Antarctic recruitment advertisements?

\section{Contrasting Reality}

When asked about their motivations for heading to Antarctica, winter-over staff have used similar language to that deployed in recruitment material. In an unpublished study by Jaksic (2017), in which former winter-overs are interviewed regarding their social experience in Antarctica, respondents reported a desire to go to Antarctica based variously upon narratives of polar heroes (a "childhood awe of Admiral Byrd"); the desire to "assist in exploration"; a fascination with wildlife ("to live among wild animals"); or simply because they "like a good adventure". In this same study, the majority of the winter-overs reported an adventure-related motivation, such as to "challenge myself", for a "sense of adventure" or to experience "wilderness". That these responses reflect the dominant ways Antarctica has been advertised is not surprising - when adventure and challenge are advertised, adventure and challenge 
are expected. As we have seen, both brands and National Antarctic Programmes have employed in their advertising heroic imagery and the promise of a far-away continent full of excitement and heroism. The well-established idea of Antarctica as a place for "soul-searching and personal transformation" (Leane, 2012, p. 133) can also be a motivating factor; In Jaksic's 2017 study, one person reported going to Antarctica because they saw it as a way to "enter the adulthood (sic)". This reveals that even those who are informed enough to be actually applying for such jobs still anticipate an experience that will test them, push them to the limits, and force them to grow up.

Those who head south for the first time need to reconcile their own imagined version of the place with the reality they encounter. Pre-existing representations of Antarctica in the minds of prospective employees must therefore be taken into account, as the contrast between imagined versions of Antarctica and the encountered reality can come as a surprise. For example, in Jaksic's unpublished study (2017), a former winter-over described McMurdo Station as being "just like a military base anywhere in the world," rather than an exceptional place unlike any other. As a result, some winter-overs have found that "McMurdo [station] is not hard enough" (Carvalho, 1996, p. 633) or voiced the opinion that "small towns - all-male [...] mining towns - in Wyoming are more difficult than McMurdo" (Carvalho, 1996, p. 633). Assistant fire chief Andre Fleuette, who has been deployed to Antarctica 16 times, also notes the discrepancy between peoples' imagined version of Antarctica and the reality encountered. In a 2017 interview with Niiler, he observed how "people go to Antarctica for the adventure, but sometimes they forget they have a job." Once down there, "they have to mop a floor or roll up a hose line. Combating the routine in such 
an amazing place can be challenging" (Niiler, 2017). Such observations are more revealing of pre-existing attitudes to the place as being somewhere tough than of any shortcoming in the facilities themselves. Discrepancy between the imagined and real Antarctic station life is arguably not necessarily detrimental; the individual will simply adjust or the reality might actually be better than anticipated. It could for instance come as a pleasant surprise that the living conditions are, in fact, as comfortable as in a hotel back home. However, when the reality does not offer a different but equally pleasant experience than expected, one is likely to experience a cognitive dissonance (Festinger, 1962). A cognitive dissonance is a state of discomfort experienced when there is inconsistency between one's belief, values and/or behaviour. In the case of individuals being deployed to Antarctica, they might experience a cognitive dissonance when balancing the time, the effort and the resources they mobilised to go Antarctica (e.g., recruitment process, leaving one's home) and the mundane experience at a comfortable station. In such a state, it is common to rationalise one's behaviour to justify it. This is a common strategy to reduce the discomfort (Elliot \& Devine, 1994). An expeditioner might for instance focus on the one-day trip to a penguin colony and the numerous pictures taken that day and neglect the time passed doing repetitive task at the station to justify their trip to Antarctica. In such a scenario, one will come back satisfied from one's expedition. This is not always the case, however; if an individual is hooked by the promise of an adventure that does not eventuate, it can be, and has been reported as, detrimental, as discussed below.

\section{'Errors of Motivation'}


The discrepancy between one's motivation for going to Antarctica and what is actually waiting for them there has been termed by Cazes and Bachelard (1989) an 'error of motivation'. These authors noticed three 'wrong' motivations for going to Antarctica, all of which negatively impact upon one's adaptation to the unusual environment. The 'motivation from lack of prior information' ['erreur de motivation par défaut d'information préalable'] states that people expecting grand voyages and adventure are less able to cope with the constraints and chores inherent to a life in a small community. The 'motivation of self-overestimation' ['motivation de surestimation de soi'] on the other hand, is concerned with the expectation that individuals will be able to test themselves against the elements and the isolation; this desire is often frustrated by the necessity to depend on others and to take part in a group life. Finally, the 'motivation of escape' ['motivation de fuite'] refers to the motivation to flee the dissatisfaction of daily life back home by going to a radically different environment - the sources of dissatisfaction, however, often remain at the forefront of people's thoughts.

The first two errors of motivation can both be fuelled by the use of extreme imagery and language in job recruitment campaigns. These 'errors of motivation' are not merely academic constructs, but rather have been observed and remarked upon by Antarctic expeditioners themselves. For example, Solignac (2004, p. 132, translated from French) mentions a winter-over who reported that "They [other winter-overs] had misconceptions, we should remove all misconceptions [...] about ideal life in polar environment or the adventurous life." While many studies and interviews to 
date relate to expeditioners who winter-over, the discrepancies between expected experience and the embodied reality are also relevant for seasonal Antarctic staff.

If those motivations are considered as 'errors' and some winter-overs think those misconceptions should be removed, it is because they can be detrimental. Expectations of adventure can lead a winter-over to experience boredom more easily. We know that boredom occurs in capsule habitats, such as Antarctic stations (Suedfeld \& Steel, 2000). For those whose very motivation for going to Antarctica is the thrill of going on an adventure, the monotonous routine of a station can be at odds with the drive for excitement that led them to apply for the job. As a result, such an individual could be expected to experience more frustration and boredom than someone who headed south expecting to have plenty of quiet time for themselves and expecting a low-stimulation environment. One former winter-over interviewed during Jaksic's unpublished study (2017) summarises it by saying that "If you're someone who gets bored easily [...] you might have a hard time [during a winterover]".

Becoming bored is not as trivial as it might sound. We know for example that boredom in the workplace is positively related to counterproductive behaviour (van Hooff \& van Hooft, 2014). Van Hooff and van Hooft also found a positive relationship between boredom and depressive complaints, one symptom often observed amongst winter-overs (Palinkas, Cravalho, \& Browner, 1995). This correlation has also been observed in Antarctica, where Biersner and Hogan (1984) found that winter-overs who reported a higher degree of boredom tended to present with higher levels of depression. This could come down to the fact that they were expecting 
plenty of excitement, and find it difficult to reconcile such preconceptions with the low-stimulation environment. As a result, they experience negative emotions because their dream of an Antarctic adventure remains elusive, and this in turn can have a negative impact on others working at the station. It should be noted that health and safety regulations, put in place by National Antarctic Programmes in order to ensure the well-being of staff, can also have a restrictive effect on the range of activities permitted, and lead to frustration. Rules do vary between programmes, with perceptions of risk mediated through the lens of each home nation.

If one individual happens to be a poor fit within the Antarctic environment, it can affect other team members. For instance, it is well documented that depressive state and irritability can reduce group harmony (Gunderson, 1968), and that the performance and satisfaction of each crewmember is influenced by group dynamics and an individual's interaction with others (Palinkas, 2003; Sarris \& Kirby, 2005). If an individual fails to adjust well, it can wear down a whole team. One former winterover, interviewed by Jaksic in 2017 (unpublished), reported the case of a nurse whose "challenge was that no one was getting sick", and got excessively bored and became depressed as a result. The interviewee recalled that all crew members were affected by the situation, and tried to reach out to help, and concluded by saying "if one of us is struggling, we tend to struggle all of us". Boredom in a remote environment can therefore also have a negative effect on all members of the team. As a result, if a whole crew is struggling to deal with a situation at the station, crewmembers might be less able to focus on their work. This is a significant concern for National Antarctic Programmes, as they rely on all team members being able and willing to give their best to their jobs. With so many resources being injected in each 
expedition, the stakes are high, and failing to obtain the expected outcomes could be disastrous.

Given the issues that can be caused by a disconnect between expectation and reality, choosing the best people for Antarctic roles is all the more important. Studies have found that some indicators should be used to screen people out during recruitment, in order to minimise problems further down the track. For instance, characteristics such as being easily bored (Palinkas, et al., 2000), or scoring high on the indicators for 'experience seeking' and 'need for challenge' (Biersner \& Hogan, 1984) have all been shown to lead to poorer job performance in remote environments. Boredom not only results in negative consequences for the individuals themselves, who might feel more depressed, but also for the National Antarctic Programme that employs them. It is thus important for a National Antarctic Programme to avoid hiring candidates who show a high expectation regarding the adventurous remote continent and to favour those who seem to have a more realistic representation of daily life on a remote station.

\section{Framing an Experience}

A humorous image posted on Antarctica New Zealand's Facebook page in October 2016 demonstrates that National Antarctic Programmes are aware of the differences between the perceived experiences of working in Antarctica and the reality. The six images presented under the headline "A Season in Antarctica" are variously captioned "what my parents think I'll be doing," "what I'll tell my FB [Facebook] 
friends I'm doing," and "what l'll actually be doing," representing different views of what a job in the far south entails. This image is based on a famous "What I Do" Internet meme, where people illustrate their jobs through the eyes of others, including their parents, their boss, and society. While these memes are designed to provoke a laugh, in the context of Antarctic employment this example carries serious undertones, and illustrates the differences between the perceptions of various stakeholders and the reality encountered.

The representations of various perceptions of the Antarctic workplace shown in the Antarctica New Zealand meme (see Figure 2) call upon common themes that have emerged in recruitment advertising. The penguin imagery in the first box ("what I hope I'll be doing") recalls the wildlife imagery used in the AAD's 2017 campaign, while the second image, showing "what my parents think l'll be doing", shows icy expeditioners sitting in blizzard conditions, linking strongly to the extremity theme. The inclusion of an image to represent "what l'll tell my FB friends I'm doing" demonstrates how one curates an Antarctic experience for those back home. In this instance, the image of a solo figure gazing out over an icy landscape is strongly reminiscent of Heroic Era imagery, and evokes the themes of heroism and extremity. In contrast, the photograph captioned "what l'll actually be doing" depicts the much less exciting and far more painstaking collection of samples. While this instance shows scientists out in the field, it could just as easily have been taken back at base, where staff members ensure the station remains operable year round. The meme succinctly illustrates the idea that when it comes to Antarctica, what is expected and what will be encountered can be very different. It is noteworthy that this has not prevented images of ice caves, field camps, and figures trekking across a frozen 
landscape from featuring in recruitment materials for the New Zealand Antarctic Programme in recent times - such imagery continues to harbour great imaginative appeal. The chance to take photographs of penguins and snowstorms, even if rare, also holds appeal for those working in the Antarctic. Although these images may not best represent expeditioners' everyday activity, they do come from a long visual tradition of depicting Antarctica as a wild and extreme location.

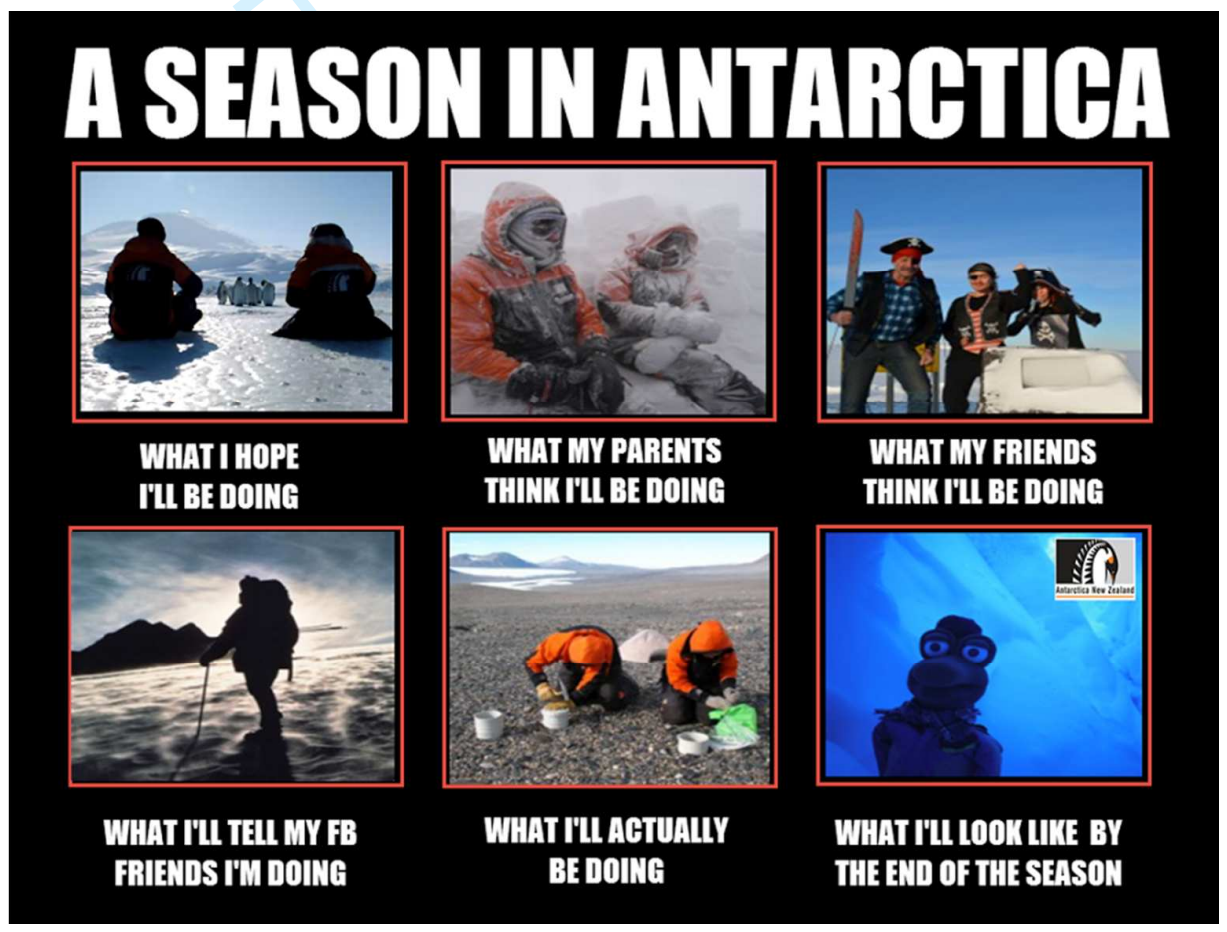

Figure 2. Internet meme 'a season in Antarctica' by Antarctica New Zealand. Image: Antarctica New Zealand

Though most job advertisements for Antarctica draw from the collective representation of the continent to attract potential applicants, there are examples of recruitment material where the mundane nature of the job is visually depicted. These 
are not as common, and also tend to be created in-house by National Antarctic Programmes, rather than by outside contractors. A recent example for a Communications and IT role with the Australian Antarctic Division (posted on their Facebook page on 6 January 2017) includes a photograph of a smiling woman sitting at a desk with two computer monitors, a phone, and a highlighted list pinned to the wall. Such imagery depicts the role far more realistically than examples where wildlife or blizzards are foregrounded, and could therefore offer a way to mitigate false expectations. This kind of imagery, which steers clear of clichéd representations of Antarctica as a place of extremes, offers new ways of framing the continent as a workplace.

The recruitment advertisements examined in this paper are by no means exhaustive, nor do they represent the only ways Antarctica has been depicted in recruitment material. They do, however, clearly demonstrate the recurrent themes of heroism and extremity, and offer a useful starting point for discussions about the links between such representations and the experiences of workers who fill the roles. Ryan et al. (2000, p. 364) have suggested that "links between human resources departments and the marketing people [need] to be developed if firms wish to produce effective recruitment advertising which benefits from the methods and devices employed in effective consumer or commercial advertising."

This advice is particularly pertinent in the Antarctic context, where recruitment material can serve the dual purpose of promoting the Antarctic Programme and finding station personnel. 


\section{Conclusion}

This paper highlights the dual themes of heroism and extremity that are present in a number of Antarctic recruitment advertisements, and argues that more could be done to ensure that Antarctic recruitment advertisements accurately reflect the job positions in question. Imagery and language are both powerful rhetorical devices, and their deployment in recruitment material needs to be carefully considered. This is particularly the case when it comes to advertising roles in Antarctica, because of the 'Antarctic imaginary', or "cluster of values, tropes and ideas" (Nielsen, 2017, p. 183) people carry in their minds. This version of the place, informed by books, films, photographs, expedition accounts, and advertising, is often built upon common tropes of Antarctic heroism, extremity, and wilderness. Although living and working conditions in Antarctica have improved markedly since the first explorers headed south over a hundred years ago, representations of the white continent continue to reprise nostalgic Heroic Era imagery, and to depict people in exceptional situations. When it comes to Antarctic recruitment material, this kind of representation comes with a price. The discrepancy between expectation and reality has implications for individuals, who may be at risk or boredom; for the team as a whole, where dynamics are impacted by the actions and attitudes of team members; and for National Antarctic Programmes, who invest heavily in logistics and training for staff, and require focussed and dedicated workers who are ready to perform their best.

Penguins and snowstorms may catch peoples' eye, but the repetition of such imagery - and language that draws out the extremity theme - can lead to unrealistic 
expectations. When confronted with an isolated and confined environment and living a monotonous routine, rather than a life of excitement, adrenalin seekers can easily lapse into boredom. The consequences of this affect all those on the station; they include staff not performing well, colleagues suffering, and ultimately lead to a less efficient operation. For this reason, National Antarctic Programmes could make an effort to depict Antarctica as it really is in order to recruit the people who would be better fit for the Antarctic work environment. By perpetuating the representation of Antarctica as a place of extremes, National Antarctic Programmes risk attracting people who are drawn to extreme situations but are not well suited to the mundane nature of many of the tasks required. By framing Antarctica as a comfortable workplace, rather than an extreme place for undertaking adventure, better outcomes could be expected for both the employing National Antarctic Programmes, and the employees who are being deployed to the far south.

\section{Acknowledgment}

We would like to acknowledge and thank the British Antarctic Survey for allowing the reproduction of the 'Field Assistant' advertisement in Figure 1, and Antarctic New Zealand for permission to reproduce the meme image in Figure 2.

\section{References}

Ackley, S. F. (2012). Book review: The global cryosphere, past, present and future, by R. Barry \& T. Y. Gan. . Arctic, Antarctic, and Alpine Research, 44(4), 520-521.

Antarctic Heritage Trust. (2017).Working at Port Lockroy. Retrieved the 15 December from http://www.ukaht.org/get-involved/jobs/port-lockroy/ 
Antarctica New Zealand. (2016). A season in Antarctica. Retrieved the 17 October 2016 from www.facebook.com/Antarctica.New.Zealand.

Australian Antarctic Division. (2002). Antarctic Weather. Retrieved the 21 February 2018 from http://www.antarctica.gov.au/about-antarctica/environment/weather

Australian Antarctic Division. (2017). Picture Yourself Here?. Voyeur, January 2017, 77.

Australian Antarctic Division. (n.d. a). Plumber. Retrieved the 15 May 2017 from http://www.antarctica.gov.au/living-and-working/experiences/plumber

Australian Antarctic Division. (n.d. b). Communications operator and supervising communications technical officer. Retrieved the 15 May 2017 from http://www.antarctica.gov.au/living-and-working/experiences/telecommunications

Australian Antarctic Division. (n.d. c). Recreation. Retrieved the 27 July 2017 from http://www.antarctica.gov.au/living-and-working/station-life-and-activities/recreation

Bamsey, M. T., et al. (2015). Review of Antarctic greenhouses and plant production facilities: A historical account of food plants on the ice. 45th International Conference on Environmental Systems, 12-16 July 2015, Bellevue, Washington.

http://elib.dlr.de/96573/1/lCES-2015-

060 Antarctic\%20Plant\%20Production\%20Facility\%20Review.pdf Retrieved the 16 June 2017.

Barbarito, M., Baldanza, S., \& Peri, A. (2001). Evolution of the coping strategies in an isolated group in an Antarctic base. Polar Record, 37(201), 111-120.

Berger, Arthur Asa. Media Analysis Techniques: Third Edition. London: Sage Publications, 2005.

Biersner, R. J., \& Hogan, R. (1984). Personality correlates of adjustment in isolated work groups. Journal of Research in Personality, 18(4), 491-496.

Borchgrevink, C. (1901). First on the Antarctic continent: Being an account of the British Antarctic expedition 1898 - 900. London: George Newnes Limited.

British Antarctic Survey. (n.d. a). Our cultural values, equality and diversity. Retrieved the 14 February 2017 from https://www.bas.ac.uk/jobs/working-forbas/our-cultural-values-equality-and-diversity/ 
British Antarctic Survey. (n.d. b). Science careers. Retrieved the 15 May 2017 from https://www.bas.ac.uk/jobs/careers-at-bas/science/

British Antarctic Survey. (n.d. c). Antarctic Fact Sheet. Retrieved the 21 February 2018 from https://www.bas.ac.uk/science/science-and-society/education/antarcticfactsheet-geographical-statistics/

Broughton, H. (2013). Behind the architecture of the UK's Antarctic station. Retrieved the 12 June 2017 from

https://www.britishcouncil.org/voices-magazine/behind-the-architecture-of-the-uksantarctic-station

Burn, D. (2009, November 16). Move to Detroit for an Epic Adventure. AdPulp. Retrieved the 26 October 2015 from www.adpulp.com/move to detroit

Byrd, R. \& Poulter, T. (1935). The Romance of Antarctic Adventure. J.W. Clement Co.

Carrère, S. (1990). Physiological and psychological patterns of acute and chronic stress during winter isolation in Antarctica, Ph.D. University of California, Irvine.

Cazes, G., \& Bachelard, C. (1989). Stress et environnement polaire. Neuro-Psy, $4(2), 84-92$.

Chaturvedi, S. (2011). Emerging science-geopolitics interface in the Antarctic: The Indian challenge. National Conference on Science \& Geopolitics of Arctic \& Antarctic: SaGAA, India, 16-31.

Coleman, M. (2013, December 9). Metallica play a dome in Antarctica. Rolling Stone. Retrieved the 15 June 2017

fromhttp://www.rollingstone.com/music/news/metallica-play-a-dome-in-antarctica20131209

Cravalho, M. A. (1996). Toast on ice: The ethnopsychology of the winter-over experience in Antarctica. Ethos, 24(4), 628-656.

De Mornay Davies, J. (n.d.). British Antarctic Survey. Retrieved the 8 February 2017 from http://www.notanyoldjo.com/British-Antarctic-Survey

Doll, R. E., \& Gunderson, E. K. E. (1971). Group size, occupational status and psychological symptomatology in an extreme environment. Journal of Clinical Psychology, 27(2), 196-198. 
Elliot, A. J., \& Devine, P. G. (1994). On the motivational nature of cognitive dissonance: Dissonance as psychological discomfort. Journal of Personality and Social Psychology, 67(3), 382.

Elmore, C. H. (1944). Quit You Like Men. New York: Charles Scribner's Sons.

Farley, R. (2008). "By endurance we conquer": Ernest Shackleton and performances of white male hegemony. International Journal of Cultural Studies, 8, 231-254.

Festinger, L. (1962). A theory of cognitive dissonance (Vol. 2): Stanford university press.

French Polar Institute. (n.d.). L'Antarctique. Retrieved the 15 May 2017 from http://www.institut-polaire.fr/ipev/informations-polaires/en-antarctique

Fung, D. (2017, April 21). Modified Hyundai Santa Fe becomes first car to cross Antarctica. Retrieved the 15 June 2017 from http://www.caradvice.com.au/544530/modified-hyundai-santa-fe-becomes-first-carto-cross-antarctical

Geoscience Australia. Australian Antarctic Territory. Retrieved the 26 August 2017 from http://www.ga.gov.au/scientific-topics/national-locationinformation/dimensions/remote-offshore-territories/australian-antarctic-territory

Glasberg, Elena. (2012). Antarctica as Cultural Critique: The Gendered Politics of Scientific Exploration and Climate Change. New York: Palgrave Macmillan US.

Guinness World Records. (n.d.). First person to cycle to the South Pole. Retrieved the 12 June 2017 from http://www.guinnessworldrecords.com/world-records/firstperson-to-cycle-to-the-south-pole/

Gunderson, E. K. E. (1968). Mental health problems in Antarctica. Archives of Environmental Health, 17(5), 558-564.

Hemmings, A.D. (2009). From the new geopolitics of resources to nanotechnology: Emerging challenges of globalism in Antarctica. Yearbook of Polar Law, 1, 55-72.

Jacob, S. (2012). High tech primitive: The architecture of Antarctica, In Ice Lab Ed Sandra Ross, 55-78. The British Council.

Leane, E. (2012). Antarctica in Fiction. Cambridge: Cambridge University Press. 
Lyne, J. (2004, December). USA's science-driven "ice highway" hitting rough sledding in Antarctica. Retrieved the 15 June 2017 from http://siteselection.com/ssinsider/snapshot/sf041213.htm

Maddison, B. (2015). Class and colonialism in Antarctic exploration, 1750-1920. London: Pickering \& Chatto.

Matuozzi, R. N. (2002). Richard Byrd, polar exploration, and the media. The Virginia Magazine of History and Biography, 110(2), 209-236.

Natani, K., \& Shurley, J. T. (1974). Sociopsychological aspects of a winter vigil at South Pole station. Human Adaptability to Antarctic Conditions, 89-114.

National Centre for Antarctic and Ocean Research, (n.d.). About Antarctica. Retrieved the 21 February 2018 from http://www.ncaor.gov.in/antarcticas

Nielsen, H. (2017). Selling the south: Commercialisation and marketing of Antarctica. In Dodds, K., Hemmings, A. D., \& Roberts P. (Eds.). The Handbook of Polar Politics (pp. 183-198). Edward Elgar Publishing.

Niiler, E. (2017). Antarctica is looking for a few good firefighters. Wired. 13 September 2017. Retrieved the 27 September 2017 from https://www.wired.com/story/antarctica-is-looking-for-a-few-good-firefighters/

Norwegian Polar Institute. (n.d). The Antarctic. Retrieved the 21 February 2018 from http://www.npolar.no/en/the-antarctic/

Palinkas, L. A. (1989). Sociocultural influences on psychosocial adjustment in Antarctica. Medical Anthropology, 12(4), 235-246.

Palinkas, L. A. (1992). Going to extremes: The cultural context of stress, illness and coping in Antarctica. Social Science \& Medicine, 35(5), 651-664.

Palinkas, L. A. (2003). The psychology of isolated and confined environments: Understanding human behaviour in Antarctica. American Psychologist, 58(5), 353363.

Palinkas, L. A., Cravalho, M., \& Browner, D. (1995). Seasonal variation of depressive symptoms in Antarctica. Acta Psychiatrica Scandinavica, 91(6), 423-429.

Palinkas, L. A., Gunderson, E. K. E., Johnson, J. C., \& Holland, A. W. (2000). Behavior and performance on long-duration spaceflights: Evidence from analogue environments. Aviation, Space, and Environmental Medicine, 71(9), 29-36. 
Peri, A., Barbarito, M., Barattoni, M., \& Abraham, A. (2000). The dynamics and the interpersonal and intrapersonal relations within an isolated group in extreme environments. Small Group Research, 31, 251-274.

Philpott C. \& Leane, E. (2016). Making music on the march: Sledging songs of the 'heroic age' of Antarctic exploration. Polar Record, 52, (6) 698-716. ISSN 0032-2474.

Recruitment Business Awards. (2010). Results. Retrieved the 11 March 2011 from http://www.recruitmentbusinessawards.com:80/categories/

Rolex advertisement. (1987). Where to spend the worst winter in the world. National Geographic Magazine, 172(3).

Rose, G. (2007). Visual methodologies: An introduction to the interpretation of visual materials, Second Edition. London: Sage Publications.

Ryan, G., Gubern, M., \& Rodriguez, I. (2000) Recruitment advertising: The marketing-human resource interface. International Advances in Economic Research, 6(2), 354-364.

Sarris, A., \& Kirby, N. (2005). Antarctica: A study of person-culture fit. Australian Journal of Psychology, 57(3), 161-169.

Scott, L. M. (1994). Images in advertising: The need for a theory of visual rhetoric. Journal of Consumer Research, 21(2), 252-273.

Singer advertisement. (1913). The Strand Magazine, 46(275), p. 89.

Sisodia, S., \& and Nimit C. (2012). Use of illustrations in recruitment advertising by service companies. Journal of Services Research, 12(2), 81-109.

Solignac, A. (2004). Influence des moyens de communication sur l'adaptation en situation d'isolement: Le cas d'un groupe d'hivernants en Terre Adélie. (Mémoire de DEA), Université de Reims Champagne-Ardenne.

Stephenson, R. (2016). \$100 Contest! Retrieved the 9 June 2017 from http://www.antarctic-circle.org/advert.htm

Suedfeld, P. (1998). What can abnormal environments tell us about normal people? Polar stations as natural psychology laboratories. Journal of Environmental Psychology, 18, 95-102. 
The Drum. (2010, March 11). Recruitment Business Awards Announced. Recruitment Business Awards. Retrieved the 4 September 2010 from www.recruitmentbusinessawards.com:80/categories

United States Antarctic Program. (n.d.). About the Continent. Retrieved the 21 February 2018 from https://www.usap.gov/aboutTheContinent/

Van der Watt, L.-M., \& Swart s. (2016). The whiteness of Antarctica: Race and South Africa's Antarctic history. In Roberts, P., Van der Watt L.-M., \& Howkins, A. (2016). Antarctica and the Humanities. London: Palgrave Macmillan. pp. 125-156.

van Hooff, M. L., \& van Hooft, E. A. (2014). Boredom at work: Proximal and distal consequences of affective work-related boredom. Journal of Occupational Health Psychology, 19(3), 348.

Vintage Sunglasses Shop. (n.d.). Ray-Ban 12k GF Deep Freeze Double Gradient Mirror Sunglasses. Retrieved the 13 July 2017 from www.vintagesunglassesshop.com/item_vs351.html

Walton, D. (2013). Global science at the end of the world. In Ross, S. (2013) Ice Lab.23-51. The British Council

Yusoff, K. (2007). Antarctic exposure: Archives of the feeling body. Cultural Geographies, 14(3), 211-233. 